\title{
REALISMO MARAVILHOSO E TRADIÇÃO ORAL NAS NARRATIVAS POPULARES DO NORDESTE BRASILEIRO EM MENTIRAS GROSSAS DE ZÉ ROTINHO, DE JOÃO NONON DE MOURA FONTES IBIAPINA
}

\author{
MARVELOUS REALISM AND ORAL TRADITION IN THE POPULAR NARRATIVES \\ OF NORTHEASTERN BRAZIL IN THE THICK LIES OF ZÉ ROTINHO, BY JOÃO \\ NONON DE MOURA FONTES IBIAPINA
}

Erika Ruth Melo Ciarlini ${ }^{1}$

Universidade Estadual do Piauí, Brasil

\begin{abstract}
RESUMO
A literatura do Nordeste brasileiro tem grande influência da oralidade. Dentre as obras desse escopo figura Mentiras Grossas de Zé Rotinho (1977), do escritor piauiense João Nonon de Moura Fontes Ibiapina. Sob o olhar de Chiampi (2015), esses textos regionais compõe um tipo literatura na América latina, neste trabalho analisado como uma face do Realismo Maravilhoso. Estudam-se o conteúdo e a utilidade narrativa dos textos a partir de Benjamin (1994), enquanto por meio das historiadoras Demes (2002) e Ribeiro e Nunes (1995) se detectam os sentidos históricos e os costumes dos locais que aparecem como cenários dos contos. Em paralelo, Câmara Cascudo (2012) é evocado para a análise da tradição popular e da oralidade na constituição da cultura nordestina do Brasil.
\end{abstract}

PALAVRAS-CHAVE: Nordeste, Oralidade, Tradição, Narrativa.

\begin{abstract}
The Northeastern Brazilian Literature has a great influence on orality. Other works of this scope figure Lies Grossas de Zé Rotinho (1977), by Piaui writer João Nonon de Moura Fontes Ibiapina. Under the gaze of Chiampi (2015), these regional texts make up a literature type in Latin America, in this work analyzed as a face of Marvelous Realism. The content and narrative usefulness of the texts from Benjamin (1994) are studied, while historians Demes (2002) and Ribeiro and Nunes (1995) detect the historical meanings and customs of the places that appear as scenarios of the Tales. In parallel, Câmara Cascudo (2012) is evoked for the analysis of popular tradition and orality in the constitution of northeastern Brazilian culture.
\end{abstract}

KEYWORDS: Northeast, Orality, Tradition, Narrative.

\footnotetext{
${ }^{1}$ Licenciatura em História e Mestrado em Literatura, pela Universidade Estadual do Piauí - UESPI. Membro do Núcleo de estudos literários Piauienses - NELIPI. Email: erikaruthms@outlook.com. É bolsista CAPES.

Este trabalho resulta de curso de Extensão da Universidade Estadual do Piauí - UESPI, intitulado "A gênese e a representatividade dos gêneros literários especulativos", de Coordenação do professor Dr. Daniel Castello Branco Ciarlini, executado no período de abril a junho de 2019, no qual o conteúdo desta pesquisa figurou como módulo ministrado pela autora. Dedica-se, portanto, o estudo aos alunos de Letras do Campus de Floriano, no estado do Piauí - nordeste do Brasil.
} 


\section{CONSIDERAÇÕES INICIAIS}

O estudo da literatura da América Latina não se desvincula da investigação de como se produzem ou circulam os textos, sobretudo porque o sistema literário também é um de comunicação, de tal forma que os diálogos estabelecidos entre as obras e a história da cultura possibilitam interpretações acerca dos contextos nos quais se inserem. Conforme mostra Antonio Candido (1999, p. 13), se toda a literatura latino-americana tem um fator comum “é em grande parte a história de uma imposição cultural". Ressignificando o precedente, porém, constituiu-se a posteriori como forma de resistência pela reivindicação do direito de narrar, o que confere ao seu conjunto de obras uma grande influência da tradição oral, com destaque aqui para o escopo produzido no nordeste do Brasil.

Pela mencionada composição cultural e pelas formas de resistência, Angel Rama (1979) observou no continente uma diversidade, não obstante subjacente às fronteiras fixadas por força da colonização, nas quais a formação citadina e o uso da palavra escrita reproduziam na latino-América os padrões que, na realidade, pertenciam ao mundo europeu. Contornado tais ditames, Rama substituiu as antigas fronteiras pela ideia de "comarcas culturais", bem como a centralidade da escrita pelo valor da oralidade, especialmente por perceber nos textos escritos a herança das línguas e performances da formação histórico-cultural da América e, de forma nítida, na estrutura dos idiomas predominantes - o espanhol, português e francês -, "la contribución fonética a la criación de dialectos, como el créo le o el papiamento antillanos, la aportación africana"” (RAMA, 1979, p. 39).

Assim, Rama acredita que um dos maiores testemunhos desse processo de resistência cultural estaria no que "se registraba en los mitos y leyendas folclóricas, vem de la transposición de los ritmos musicáles a las estructuras verbales" " (RAMA, 1979, p. 39), culminando na arte os detalhes da história e da cultura de um povo. Nesse conjunto

\footnotetext{
2 "A contribuição fonética à criação de dialetos como se criou o papiamento antilhano, a expressão africana" (RAMA, 1979, p. 39).

3 "Se registrava nos mitos e lendas folclóricas, vem da transposição dos ritmos musicais às estruturas verbais" (RAMA, 1979, p. 39)
} 
de obras destacam-se aquelas produzidas nas comarcas Andina e Amazônica, onde situam-se as áreas do Sul do Brasil e as correspondentes ao Norte e Nordeste, que o chamaram atenção pela diversidade da literatura produzida e pelo embasamento dos textos na vida cotidiana. Rama diziam ser "contribuciones concrectas, las más generales derivadas de uma cosmovisión cultural testimoniada em múltiples operaciones literarias, desde los proverbios haitianos hasta los Malos brasileños" "(RAMA, 1979, p. 39).

Das obras desse tipo, destaca-se do nordeste do Brasil o livro Mentiras Grossas de Zé Rotinho: contos populares do folclore no Piauí, de autoria de João Nonon de Moura Fontes Ibiapina, que foi publicado em 1977, compondo-se de 24 contos e prefaciado pelo folclorista Luís da Câmara Cascudo. A edição saiu pelo Caderno de Letras Meridiano, conforme é mencionado nas informações da obra, e parece uma continuação de Lorotas e Fabulações de Zé Rotinho, de 1967, que conferiu ao autor o Prêmio Mobral de Literatura brasileira em 1972. Pela voz de um contador de histórias e com artifícios de hipérbole, os textos abarcam as lendas amazônicas, as tradições dos moradores do nordeste do Brasil e as negociações com a cultura do colonizador da América Latina.

Fontes Ibiapina despontou na literatura em 1950, com a escrita de contos e, paralelamente, dedicou-se à publicação de romances e à crítica literária em jornais, sendo eleito em 1968 para a Academia Piauiense de Letras. Seus romances mais conhecidos são Palha de arroz (1968), Chão de meu Deus (1972), Tombador (1971), Nas terras do Arabutã (1984), Curral de assombrações (1985) e Vida gemida e sambambaia (1985). Quanto à contística, além das obras citadas, existe ainda Congresso de duendes (1969) e os contos apartados de livros: Trinta e dois e tangerino (1954) e Dr. Guilherme de Chanfurbois (1968); contos publicados em periódicos nacionais para os quais o autor contribuía, tais como Forrozeiro (1960); e os que estão em manuscritos, sem publicação: Palestra de comadres (1950) e Zeca Puciano (1962).

O escritor optou por representar, em todos os seus textos, um nordeste do Brasil pela ótica do próprio povo, dando ênfase à cultura do território por meio de ações cotidianas, interligadas às demais tradições latino-americanas. O cenário das histórias se passa em diferentes cidades, com linguagem e formas de viver dos tipos humanos, algo

\footnotetext{
4 “Contribuições concretas, geralmente derivadas de uma percepção cultural testemunhada em múltiplas manifestações literárias, desde os provérbios haitianos até os causos brasileiros” (RAMA, 1979, p. 39).
} 
que conferiu à sua produção um estilo peculiar e regional. Por isso, trazendo apelos ao fantástico e ao mágico, Fontes Ibiapina fez das tradicionais histórias do nordeste o palco de características do realismo maravilhoso da América Latina, tendo como cenário as terras de seu estado de origem, o Piauí, um território, antes, corredor de passagem entre as regiões norte e nordeste do Brasil, por isso comportando a memória oral das gentes que por ali passaram.

Para dar conta desse contingente, tradição popular, as lendas, costumes e recordações figuraram como conteúdo dos artifícios narrativos empregados por Fontes Ibiapina que, se analisados pela ótica de Walter Benjamin (1994, p. 199), no livro se organizam em dois atributos relacionais ou "famílias de narradores": histórias e tradições herdadas de outros lugares, por narradores viajantes, e aquelas que se constituem a partir da (re)contação dos narradores fixados em suas terras. "O saber, que vinha de longe - do longe espacial das terras estranhas, ou do longe temporal contido na tradição", tecendo, ambas “uma dimensão utilitária" (BENJAMIN, 1994, p. 200) que é inerente a esse tipo de literatura: o repasse da sabedoria popular. Outrossim, o terreno do Maravilhoso "o extraordinário e o miraculoso são narrados com a maior exatidão, mas o contexto psicológico da ação não é imposto ao leitor" (BENJAMIN, 1994, p. 203). Por essa liberdade narrativa, outras tramas da mesma fábula são repassadas, alimentando o tradicional saber e às vozes do contar da mesma história, em diferentes variações, possíveis de se encontrar no interior do nordeste do Brasil.

\section{REALISMO MARAVILHOSO E LENDAS PIAUIENSES NOS CONTOS DE FONTES IBIAPINA}

O Realismo Maravilhoso, de acordo com Irlemar Chiampi (2015), "recobre, nesta acepção, uma diferença não qualitativa, mas quantitativa com o humano; é um grau exagerado ou inabitual do humano" (CHIAMPI, 2015, p. 48); ou seja, um tipo de especulação que mantém o humano como diretriz, deformando-o, em níveis variados, para lhe dar maior notoriedade. 
No conto "Pescaria de Arranca", o segundo da obra Mentiras Grossas de Zé Rotinho, o cultivo da mandioca foi representado, assim como o costume de colhê-la para a venda e a produção da farinha, no entanto algo novo decorre no relato, pois ao invés de mostrar como as mandiocas foram arrancadas, a narrativa apresenta uma cena inerente ao realismo maravilhoso, que é a quebra do ordinário em nome do riso:

Determinado dia observei estar minando água num tronco de mandioca. Puxei um torrão e a água estufou pra cima, chega borbulhava. E o interessante é que tanto saía água como peixe. Cada piau desse tamanho, de tão grande. Curimatá até de metro, pesando coisa de uma arroba. Então observei que em cada pé de mandioca se dava a mesma coisa. Um peixe de ninho. Dizendo melhor, que errei na regra: um ninho de peixe (IBIAPINA, 1977, p. 26).

Como se vê, seria, grosso modo, um escapar ao que se entende do corriqueiro, pois "não se trata de grau de afastamento da ordem normal, mas da própria natureza dos fatos e objetos" (CHIAMPI, 2015, p. 48). A realidade, por seu turno, permanece: o trabalhador nordestino em sua colheita e pescaria; a paisagem brasileira de plantações próximas a pequenas lagoas; o destaque da mandioca, alimento propagado pela tradição dos povos indígenas do Brasil; o Piau e o Curimatá, que são peixes típicos do estado do Piauí; a linguagem habitual do morador interiorano, permeada por suas comparações de "Ninho", "estufou pra cima", "desse tamanho", "chega borbulhava", "que errei na regra”, por meio das quais o maravilhoso desvela-se, na sutil deformidade do consenso a respeito de como essa realidade funciona.

Confirmando a abertura do conceito, Fontes Ibiapina em "Começo de conversa", ao introduzir Mentiras Grossas de Zé Rotinho, afirmou que a realidade permaneceu como norteadora da narrativa, porque compunha-se de "estórias moduladas no cerne de nossos costumes, meios e condições de vida, crendices e superstições" (IBIAPINA, 1977, p. 13). Ainda, ao exaltar o folclore do Brasil, destacou que a tradição de contar tais histórias esteve "alicerçada na padronagem ecológica que, com semelhanças e variações nítidas entre outras partes do mundo, reflete o enciclopedismo unigênito, a psicologia coletiva de um povo" (IBIAPINA, 1977, p. 13); portanto, tais histórias em sua produção, mesmo com recorrência em outros povos ou estados do país, ligam-se às realidades do morador do Piauí.

Nesse sentido, "longe de ser um modismo terminológico, o maravilhoso tem servido para designar a forma primordial do imaginário de obras de todas as latitudes culturais" (CHIAMPI, 2015, p. 49), o que foi outro dado em destaque para o autor, ao 
admitir que seu texto integra-se à constituição constante, "existente em outras paragens desse Brasilão sem fim, mesmo que com outra forma" (IBIAPINA, 1977, p. 13), justamente porque o veículo de propagação das narrativas foram as modulações orais, criando "literatura saborosa que nos foi legada por nossos ancestrais, através dos tempos, naquelas chacundas palestras de ponta-de-terreiro, nos idos e nunca esquecidos dias da infância" (IBIAPINA, 1977, p. 14).

A referência feita pelo escritor remonta às conhecidas no interior do Brasil como "estórias de pescador" ou "histórias de caçadas". Eram os relatos de aventuras pelas madrugadas dos caçadores entre os matagais, lidando com animais ferozes e com o medo da escuridão, e dos pescadores, sobre mares e rios em que pegaram grandes peixes ou presenciaram fenômenos inexplicáveis. Existem, ainda, aquelas nomeadas de "histórias de trancoso", onde o suspense é explorado para, ao final, provocar o riso ou o susto.

Traçando um percurso histórico das "Histórias de trancoso", Camara Cascudo (2012) afirma essa tradição advir da Europa, então chegando ao território nordestino por meio da colonização. $\mathrm{O}$ pesquisador diz que naquele continente são conhecidos como "contos de trancoso", muito comuns ao interior de Portugal; pequenas histórias as quais se tinha costume de contar à vizinhança. Os relatos aconteciam ao redor de fogueiras, nas noites frias ou em noites de lua cheia, em sua maioria contadas para assustar as crianças. O costume, trazido à América, para Cascudo, tornou-se o tipo de narrativa também responsável por propagar as tradicionais lendas no interior do norte e nordeste do Brasil, misturando o conhecimento popular, a fauna e flora brasileira, bem como a mitologia indígena, tais como as lendas do Mapinguarí, Lobisomem, Mula-sem-cabeça, Chupa-cabras, Peixe-grande etc.

No mês de junho, época da comemoração das tradicionais fogueiras juninas e da primeira colheita após a chuva no nordeste brasileiro, se reuniam ao redor do fogo os jovens e os mais velhos, momento que cantavam-se músicas locais, ouviam tais histórias, partilhavam-se as comidas típicas e eram preservados os costumes de compadrio e danças. Ribeiro e Nunes (1995, p. 353) relatam que o mês de junho no nordeste brasileiro é época em que se fazem fogueiras e celebram-se as novenas, assim chamadas porque "as preces são feitas durante (9) nove dias. Começam com grupo pequeno que sai de 2 para as 3 horas da tarde em peregrinação”. Acontecem as missas 
nas capelas dedicadas aos santos comemorados nesse mês: Antônio, nas datas de 12 e 13; João, nos dias 24 e 25; e Pedro e Paulo, em 28 e 29 de junho.

Em todos os nove estados do nordeste queimam-se as fogueiras à noite, ao final das novenas, pois a fogueira relembra a forma como os santos homenageados morreram, em sua maioria decapitados ou queimados pelos soldados do antigo império romano. Após as preces, acontecem as tradicionais danças, contações de histórias ao redor das fogueiras e partilham-se comidas feitas com o principal produto da colheita do nordeste: o milho, entre elas o bolo de milho caseiro e o "Mugunzá", um caldo feito de leite, açúcar e milho cozido.

Alguns desses eventos ganharam dimensões grandiosas, tais como as festividades de Campina Grande, Petrolina, os "Arraiais" de Recife e as danças de boi em São Luiz do Maranhão, que acontecem no dia 25, dia de São João, conhecido pelo cristianismo como primo de Jesus; o livro dos cristão conta a vida do homem, que vivia entre os pobres e batizando os que se arrependiam de seus pecados e "em homenagem a este santo que se dança o Bumba-Meu-Boi” (RIBEIRO; NUNES, 2012, p. 349).

A particularidade do estado do Piauí, onde Fontes Ibiapina nasceu, diz respeito às comemorações da população acontecerem de forma mais reservada às missas em capelas e, após, em suas próprias casas, às conversas e histórias noturnas, contadas ao redor das fogueiras, onde tradicionalmente come-se o peixe e soltam-se foguetes. $\mathrm{O}$ ritual acontece sobretudo nos dias doze e treze de junho, quando ocorrem homenagens ao Santo Antônio, quando são praticadas as "danças caipiras, da rancheira e a quadrilha", pois o homem é "considerado protetor dos pobres e das moças que desejam maridos" (RIBEIRO; NUNES, 2012, p. 349), com destaque para as cidades de "Campo Maior e Jerumenha, onde é padroeiro" (RIBEIRO; NUNES, p. 349).

Nas outras épocas do ano, o luar em sua fase cheia provocava a mesma reunião, que a vizinhança, ao lado das casas, espaços chamados "Pontas-de-terreiro", amarrava redes e sentava-se no chão para ouvir as histórias dos velhos. A energia elétrica só chegou ao interior do Brasil à segunda metade do século XX, algo que fortificou o costume da fogueira e dessas reuniões à luz da lua. O luar e a fogueira com amigos ou familiares são, inclusive, imagens recorrentes na arte do país, em especial na música sertaneja e na literatura regionalista, estas artes que foram cunhadas aos arredores do fogo e sob a luz da lua, em rodas de violeiros e contadores de histórias. 
Em "Espera de onça", Fontes Ibiapina demonstra uma das "histórias de trancoso" contadas para assustar as crianças, em uma noite de luar, pela voz de seu Zé Rotinho:

\begin{abstract}
Não sou, de maneira alguma, dado a dar muito valor a determinadas fantasias. Mas acho que aquela danada era mesmo mandingueira. Basta se saber que um animal deixar o couro todo e correr, só sendo mesmo empautado do capiroto das profundas. Outra coisa: essa uma outra espera que montei em noite de luar. Basta-se saber que houve até eclipse, lua cris de sete e oito horas da noite. E como vocês sabem, eclipse de lua só se dá em noite de lua-cheia, como no sol só em dia de lua-nova. Pois a lua foi cris, como já disse naquela noite. Depois, o eclipse passou e ficou um clarão que era uma belezura. Além do mais, era agosto, o mês de luar mais claro aqui em nossa região. Pois de um momento pra outro se formou um mormaço que acabou com o clarão da lua. Daí a pouco ouvi aquele leco-leco-leco-leco da onça bebendo água (IBIAPINA, 1977, p. 58).
\end{abstract}

Observando acima, pode-se ver o culto à luminosidade do fogo e da lua transposto para a narrativa, identificando-se a luz como elemento de revelação e sua ausência como uma possível presença do mistério e da aventura. O sobrenatural aparece em momentos em que a natureza cria o conflito entre a luz e as sombras, como acontece na simbologia do eclipse lunar e no atrelamento direto das luzes do sol com a da lua. Portanto, à medida que a luz se afasta, se exige maior vigilância. A fantasia, entretanto, é evocada, ao passo que pequenas luzes se confrontam com o escuro. A verdadeira claridade da lírica do sertanejo residiria, então, à parte, enclausurada em seu espaço poético. Nessa mesma poeticidade da luz, as velas estão sempre nas histórias de procissões de fantasmas que caminham pelas madrugadas do nordeste. As historiadoras Ribeiro e Nunes (1995, p. 355) descrevem a lenda: "costumavam fazer a procissão das almas, na noite de quinta para sexta-feira santa" e que a procissão com os mortos carregando as velas nas mãos: “costumava sair da porta do cemitério. Era costume não se abrir as janelas das casas para olhar" e que "quem estivesse dormindo ouvia o matraquear soturno fazendo ritmos, às vezes controlados, que passavam pelas ruas da cidade. As pessoas sequer acendiam as velas dentro das casas".

Ainda, é pela luz da lua que ocorre a transformação dos seres sobrenaturais. Porque a luz para o lirismo parece um elo entre o mundo corriqueiro e o universo da poesia. Já a onça-pintada, animal característico da fauna do Brasil, aparece rodeado pelo seu mistério no conto "Espera de Onça". Esse felino de hábito noturno, temido pelos caçadores, quando achado nas bordas dos riachos ao beber água era caçado e sua pele trazida como troféu do corajoso caçador. Era costume esperar os animais aos quais 
desejava-se caçar nesses lugares, somente que, na narrativa do conto, a onça não aparece como animal comum, mas com seu mistério multiplicado, pois possuía a capacidade de deixar sua pele e correr, aterrorizando o caçador à sua espera. Essa prosa de Ibiapina vai ao encontro da característica própria dos contos maravilhosos, que se identificam como "um tipo de relato, cuja estrutura permite distinguir de outras realidades" (CHIAMPI, 2015, p. 50) e sua "extraordinariedade se constitui da frequência ou densidade com que os fatos ou os objetos exorbitam as leis físicas e as normas humanas" (CHIAMPI, 2015, p. 48).

$\mathrm{Na}$ análise dos contos, ainda percebe-se que na produção desse escritor "há a razão histórica que legitima o maravilhoso como identificador da cultura americana" (CHIAMPI, 2015, p. 50), pois o maravilhoso de Mentiras Grossas de Zé Rotinho empresta a pena à escala dos contadores de histórias da América Latina, como na resposta de um povo, historicamente vítima da nomeação autoritária de outras culturas, ora pela colonização ora pelo imperialismo, por meio da literatura, a qual aparece, transmutada pelo riso e pelo susto, em reivindicação identitária da palavra.

Com isso, a supremacia da palavra escrita e a autoridade de nomear o seu mundo por outras gentes fizeram parte do incômodo de Fontes Ibiapina, mais expresso na afirmação de que suas histórias, na verdade, são "obras-primas diretamente descendentes da sabedoria popular, cujos autores seriam hoje, não fossem analfabetos, figuras de relevo" (IBIAPINA, 1977, p. 14) e sempre defendendo-as pela tradição, de que "surgiram as estórias em prosa, contadas em ponta-de-terreiro, ao pé do fogo, ao clarão do luar" (IBIAPINA, 1977, p. 15).

Sobre a peculiaridade dessa literatura, Luís da Câmara Cascudo (2012), em seu livro Literatura oral no Brasil, defendeu que as contações de histórias funcionam, na verdade, como introdução a outro tipo de cânone. A conclusão do autor deu-se quando, ainda menino, correlacionou autores e obras brasileiras:

Fui para o curso secundário e pude ver a diferença entre as duas literaturas, ambas ricas, antigas, profundas, interdependentes, ignorando as pontas comunicantes. Inconscientemente confrontava ritmos e gêneros, a exigência do dogma culto e a praxe dos contadores sertanejos, setissílabas, décimos, pé-quebrado, a ciência do 'desafio'. Todas as outras literaturas foram elementos de comparação (CASCUDO, 2012, p. 7). 
Por essa análise de Camara Cascudo se vê a existência de um cânone repassado como referência para a língua portuguesa escrita e outro que se propaga na oralidade. $\mathrm{O}$ primeiro se dá pelo aprimoramento, pela técnica da edição e no interior das palavras impressas, enquanto o último se modula no "desafio" ou no improviso, sem deixar de preservar o saber representado. Na descrição, Cascudo acredita na convivência dessas duas literaturas, dizendo que são interdependentes.

$\mathrm{Na}$ literatura oral, levando para a obra a fala pelo que aprendeu dos antigos, o narrador aparece como condução definidora. Esta qualidade desse tipo da literatura na América dota os contos regionais do maravilhoso. As Mentiras Grossas de Zé Rotinho, nesse sentido, imprimem de maneira escrita uma tradição surgida na oralidade, pois o texto registra expressões nitidamente orais, tanto na estrutura das palavras que imitam aquelas usadas pelo morador local, como quando o escritor diz que "o povo conta estórias e conta-as como de autoria de um fulano de tal dos Anzóis Carapuça que em outros tempos foi tido, havido e conhecido" (IBIAPINA, 1977, p. 16), a quem pertence o que, antes, não foi escrito, mas repassado pelo relato oral.

Portanto, a reivindicação da voz e da nomeação do mundo apropria-se do saber e consagra-o à figura respeitada do velho contador de história. O sentido histórico que confere essa forma de narrar ao Realismo Maravilhoso, para Irlemar Chiampi (2015) nasce da necessidade de explicar o exótico do continente americano, pois a diversidade do território e suas tradições eram pouco compreendidas pelo colonizador, este que as atribuiu sentido arbitrário. Assim, o maravilhoso em sua função histórico-social americana ressignifica o espaço e a cultura do continente a partir da tradição e do olhar de seus próprios moradores, como que questionando o direito de voz da tradição cultural da oralidade, bem como o de sujeitos históricos, visto que dificilmente esses fatos e pessoas que narram são encontrados em documentos políticos e estatísticas, nos quais a história da américa latina embasou-se por muitos séculos.

Chamou-se por muitos anos esses tipos de literatura como partes do realismo mágico, entretanto, modificando-se a concepção, destacadamente no século $\mathrm{XX}$, ao perceberem que, na estrutura da narrativa maravilhosa mostrava-se um diferencial: o local do narrador, que é anunciado e condutor da história. Esse fato define-o e o distingue de outras categorias do especulativo, tais como o mágico e o fantástico. A diferenciação, para Chiampi (2015), seria o efeito psicológico, contrastando do horror, 
que choca, e da ficção científica, onde o valor é mais da cena que do relato. Por esse ponto de vista, apesar de abordar artifícios do mágico, do fantástico e a utilização do medo, o maravilhoso aparece como abrangente, porém com ênfase no sentido do relato.

Nessa intenção, mostra-se o caso de Mentiras Grossas de Zé Rotinho, pois Fontes Ibiapina, após descrever o seu contador de histórias, de modo eloquente, o entrega à autoridade de contar: "Pois ele mesmo vai lhe contar interessantes estórias, prezado leitor amigo. A ele passamos a palavra. FALA ZÉ ROTINHO!” (IBIAPINA, 1977, p. 17). Ademais, o porquê não se entende apenas pela estrutura narrativa ou histórica, ambas já explicitadas, porém, no caso piauiense, grandemente, em seu contexto: na figura sagrada que o ato de repassar saberes representa.

\section{O LUGAR DA PALAVRA NO REPASSE NARRATIVO DA TRADIÇÃO NORDESTINA}

Nas culturas orais a palavra contém um quê de sacralidade, conferindo-lhe, assim, como nos contos de Fontes Ibiapina, o caráter lírico do maravilhoso, porque, ao invés do encanto, o que lhe dá autoridade sobre a significação das coisas é a tradição. Essa sacralidade da palavra foi o que levou Walter Benjamin (1994, p. 197) a afirmar que o narrador "é algo de distante, e que se distancia ainda mais", pois para o estudioso a (re)contação das histórias são características da narrativa, porque ela integra uma gama de vozes, na realidade, muito antigas e distantes, que são evocadas a cada vez que uma história é contada a um grupo ou região. Para ele: "a experiência que passa de pessoa a pessoa é a fonte a que recorrem todos os narradores. E, entre as narrativas escritas, as melhores são as que menos se distinguem das histórias orais contadas pelos inúmeros narradores anônimos" (1994, p. 198).

Logo, é nesse processo de recontar que a palavra transforma-se no que Benjamin chamou de "o lado épico da verdade" (1994, p. 201), ao comparar as narrativas aos poemas épicos repassados oralmente pela tradição antiga, com a finalidade de fixar uma sabedoria, a qual conceitua como "conselho tecido na substância viva da experiência" 
(1994, p. 200). Nisso, contar a história é um lugar de autoridade e "dar a palavra" é sinônimo de expor a memória e a honra ao público, porque "o narrador retira da experiência o que ele conta: sua própria experiência ou a relatada pelos outros. E incorpora as coisas narradas à experiência dos seus ouvintes" (1994, p. 201).

Benjamim defende que o repasse, o vínculo com a experiência e o alicerce da tradição "esclarece[m] a natureza da verdadeira narrativa" (1994, p. 200). No livro de Fontes Ibiapina, se isso não é quando a história começa pela afirmação de que o narrador a presenciou, ele usa a expressão "Diz que..." ou que alguém relevante o disse. É dessa forma que o conto "Peixe Grande", uma das mentiras de Seu Zé, foi registrado por Fontes Ibiapina:

Rezemos pra Nossa Senhora dos Navegantes e Nossa Senhora da Guia, que é o peixe grande! Nisto o tal peixe botou a cabeça de fora. Diz que cada olho do tamanho dum tacho. O tal barco diz que até ia correndo em velocidade, mas foi logo que mancou a carreira (IBIAPINA, 1977, p. 65, grifo nosso).

O "Diz que..." então funciona nesse texto como autorização do real contador. A expressão também ressalta a carga da tradição oral contida. A função das duas palavras é quase que pronominal, pois retornam ao nome do portador do relato, substituindo-o e, ao mesmo tempo, o fazendo presente no contar de sua história. No conto "Peixe grande" ainda surgem na representação duas, dentre as mais conhecidas, crenças do morador nordestino, que são as criaturas conhecidas pelas histórias antigas, como o "assobiador", "os peixes-fantasmas", estas tais como O Peixe-grande, que é lenda no norte e nordeste do Brasil; e, outra, que é a virgem Maria, aparecendo como o refúgio da promessa do sertanejo pela chuva, pela boa caça e pescaria e, como no conto acima, pela proteção diante do sobrenatural.

A lenda do peixe, tradicional do nordeste, comum a todo o interior brasileiro, e a crença na santa, trazida pelo colonizador à América, especialmente pelos católicos espanhóis e portugueses do século XVI, configuram as duas tônicas da narrativa elucidadas por Walter Benjamin (1994) que são "o narrador como alguém que vem de longe" (BENJAMIN, 1994, p. 198) e "o homem que ganhou honestamente a vida sem sair de seu país e que conhece suas histórias e tradições” (BENJAMIN, 1994, p. 198-199). Para ele "essas duas famílias, como já se disse, constituem apenas tipos fundamentais" (BENJAMIM, 1994, p. 199), porém imprescindíveis em sua análise, pois “a extensão real do reino narrativo, em todo seu alcance histórico, só pode ser 
compreendido se levarmos em conta a interpenetração desses dois tipos" (BENJAMIN, 1994, p. 199).

No conto "Peixe-Grande", Fontes Ibiapina fez de estratégia da sua narrativa os dois tipos que são mostrados por Benjamin (1994), quando articula o teor lendário interno ao Brasil com uma devoção externa para promover o sentido e a catarse do maravilhoso. Destarte, consegue unificar a devoção às duas nomenclaturas da Mãe do Cristo, que é comum do Litoral ao interior do Nordeste, como numa forma de ganhar pela religiosidade os dois públicos. Assim, as narrativas do nômade e as do sedentário em Fontes Ibiapina compõem o que Benjamim chama de "sistema corporativo" da arte narrativa, onde "associava-se o saber das terras distantes, trazidos para casa pelos imigrantes, com o saber do passado, recolhido pelo trabalhador sedentário" (BENJAMIM, 1994, p. 199). Os dados, entretanto, são detalhados pela análise histórica, sobretudo pelo teor de tradição encontrado no relato, que se identificam os vínculos territoriais e culturais com o "real" em que o maravilhoso se revela.

No interior do estado no qual nasceu Fontes Ibiapina, existe o rio Parnaíba como principal, banhando o território e dividindo-o dos demais estados, enquanto pequenos rios são encontrados tecendo vínculos com a bacia no restante das terras. No litoral, o rio corta as cidades, todavia existindo entradas do mar. Os cultos nas regiões ribeirinhas e marinhas distinguem-se, embora mantenha uma devoção comum.

A tradição do Litoral chama Maria mãe de Deus de Nossa Senhora das Candeias ou dos Navegantes, pois os pescadores preparam candeias de flores para jogá-las nas águas no dia 2 de fevereiro de cada ano. A festividade corre em paralelo com as oferendas a Iemanjá, culto também muito forte no restante do litoral nordestino, especialmente em Salvador, capital da Bahia. O marianismo no litoral é forte e a principal cidade do norte, Parnaíba, que leva o nome do rio, tem por padroeira Nossa Senhora da Graça, cuja imagem remonta à amamentação do menino Jesus. A tradição do sul e centro-sul do estado chamam-na de Nossa Senhora da Guia e dos Remédios, pois a leva de imigrantes árabes e espanhóis é preponderante na influência dessa tradição. E, ao lado do culto, as cidades elegem santos como padroeiros locais, com destaque para São José e São Pedro de Alcântara, quando na data das festividades ao primeiro se demarca o dia de chegada da chuva. A tradição mostra-se vinculada à 
fertilidade da terra, seja por meio do rio, da chuva ou da ideia que a figura feminina de Maria repassa.

As historiadoras Verônica Ribeiro e Maria Nunes relatam as festividades ocorridas no interior do Piauí, recorrente na região em que o escritor Fontes Ibiapina nasceu, na qual a devoção dos pescadores é idiossincrática àquela representada pela sua narrativa. Registram que, ao redor do principal rio do Piauí, são notáveis as “dezenas de tendas [que] fazem coloridas manifestações à rainha do mar nas areias do rio Parnaíba, onde são jogadas as oferendas rio abaixo" (RIBEIRO; NUNES, 1995, p. 350).

Em alguns locais, não havendo grandes festividades em oferenda à virgem Maria ou devoção a Iemanjá, há apenas o costume de colocar candeias com velas acesas nas portas, no dia devotado ao festejo religioso de Nossa Senhora dos navegantes. A população acredita que, com isso, se alcança boa pescaria durante o ano e a luz nas janelas das casas afugenta as forças do mal.

Nos locais onde ocorrem os tradicionais "festejos" ou "quermesses", "durante o dia há competição de natação e corridas de canoas. Existe também uma procissão fluvial e marítima" (RIBEIRO; NUNES, 1995, p. 349). Na pesquisa "Manifestações folclóricas" (1995) as historiadoras mostram que os mesmos rituais são repetidos em devoção a outros santos, como São Pedro, São José, São Gonçalo e Santa Luzia. Os eventos "encontram-se enraizados em uma herança deixada pelos ibéricos e introduzida no Brasil desde o século XVI” (RIBEIRO; NUNES, 1995, p. 347), tendo, muitas destas, assumido outras datas e diversas manifestações desde o período colonial.

Já em regiões do centro, próximas às bacias do Rio Parnaíba e São Francisco, Nossa Senhora da Guia é uma crença que firmou-se pela migração Sírio-Libanesa, pois este povo, atraído pelos rios que banham as fronteiras do Maranhão, Piauí e Pernambuco, e fugindo das guerras do Império Otomano, acreditavam que a "virgem da Guia" os fazia acertar as rotas, guiando-os na escuridão dos oceanos e os livrava dos ladrões de mercadorias. Da Guia é o nome dado à mãe de Jesus na Igreja Ortodoxa e no Oriente Médio e assim chamada pelos povos árabes, que foram influentes no comércio nas regiões das cidades nordestinas durante os séculos XIX e XX. Uma das maiores levas sírio-libanesas vindas ao nordeste fixou-se ao redor do Rio Parnaíba, em numerosas famílias que, segundo a descendente e escritora Josefina Demes (2002, p. 630), são ainda visíveis pelos locais onde passaram, “em seu traçado arquitetônico, nos 
hábitos e costumes de sua gente, sobretudo na culinária, muito da milenar cultura árabe e de suas tradições".

Em Floriano, cidade que ladeia o município de Picos, o último onde o escritor Fontes Ibiapina nasceu, é possível encontrar os mais antigos moradores chamarem os Sírios e Libaneses de "carcamanos", referindo-se aos comerciantes orientais instalados. Como descendeste dos árabes Demes incomoda-se com a nomeação, e diz: "Não tinham nomes...eram os carcamanos. O tempo, porém, encarregou-se de sanar essa injustiça" (DEMES, 2002, p. 638). Na cidade, existe santuário para a imagem de Nossa Senhora da Guia e, ainda, muitas mulheres carregando o nome da santa. As fontes apontam que uma ala do catolicismo e culto à Guia foram trazidos pelos sírios, da região das montanhas próximas de Damasco, capital da Síria, inicialmente pela família Zarur:

\footnotetext{
Presença em terra florianense data de 1889, com a chegada do pioneiro Antun Zarur, natural de Malulah, uma aldeia encarava nas encostas do monte Kalamum, a poucos quilômetros de Damasco, como já foi dito. Tangido por razões de ordem econômica e religiosa emigrou para o Brasil em busca de melhor sorte. Era católico do rito oriental e padeiro de profissão. Dando continuidade às atividades na nova pátria (DEMES, 2002, p. 631).
}

A obra na qual encontra-se esse citado texto foi um dos raros relatos historiográficos da imigração árabe ao Piauí, majoritariamente reconhecida pela tradição oral e pelas manifestações culturais do lugar, então escrito por uma descendente, Josefina Demes, que se tornou escritora e professora da região na segunda metade do século XX. O povo vindo ao Brasil trazia uma ala do cristianismo católico em vigor na região de Damasco, em que o culto à virgem da Guia ganhou proporções e, ainda, perseguição, um dos motivos da fuga, impetrada por grupos divergentes ao cristianismo. A autora, Demes (2002), conheceu Fontes Ibiapina e integrou, assim como este, academias de letras piauienses.

A breve observação dos autores contemporâneos e amigos de Fontes Ibiapina, tais como Álvaro Ferreira, H. Dobal, José Bruno dos Santos (ainda vivo) e Josefina Demes, percebe-se a forte ligação com a terra nordestina, com as histórias de sua gente e com os saberes e tradições repassados pelos mais velhos, bem como registram em seus textos, como Bruno dos Santos em Transpondo barreiras, a luta para sobreviver à fome e à seca do Nordeste, o qual, como tantos outros escritores da região, anotou a fabulação unida àquilo que ouviram e viveram. As lendas, histórias, cultos, como o da Guia e a grande presença da fauna e da flora nas histórias povoam as páginas 
O conto "Piexe-grande", por sua vez, parece mesclar a lenda americana sobre o bicho gigante que emerge nas águas do Brasil para devorar embarcações, a religiosidade do piauiense em devoção aos santos católicos e a tradição das "histórias de trancoso", as quais, em sua versão nordestina, criavam atmosfera de suspense, apenas quebrada pelo riso na conclusão, trazendo à luz o traço maravilhoso da lenda: a quebra da ordem natural de coisas e animais e o efeito que lhe é particular (o riso ou o susto).

No final de "Peixe-grande", Fontes Ibiapina mostrou o resultado da situação, pois o peixe supostamente engolira as mercadorias do barco, que eram alguns animais, como porcos e galinhas, cana-de-açúcar, móveis de madeira e, no balançar das ondas, um pobre idoso também caíra no rio, sendo engolido pelo peixe. Mas o narrador Zé Rotinho conta o que testemunhou ao final:

E mataram mesmo o danadão. Mais de cem homens arrastaram o monstro pra fora do rio. E o mais interessante de tudo: quando abriram a pança do danado, lá estava o velho sentado na cadeira, bem refestelado, chupando cana e jogando os bagaços para o porco (IBIAPINA, 1997, p. 66).

Conforme acima, os contos maravilhosos são identificados pelo "efeito que provocam tais intervenções no ouvinte ou no leitor" (CHIAMPI, 2015, p. 49) e, neste caso, o sorriso, pois no cotidiano, dificilmente, se encontraria um peixe tão grande a ponto de mobilizar cem homens, muito menos, que um idoso engolido permanecesse vivo, sentado, alimentando um porco no interior da barriga do bicho.

O exagero contido no texto, para Benjamim (1994, p. 203) foi segurado pela base construída com a contação da mesma história ao longo dos séculos, pois essa narrativa registrada por Ibiapina "não é mais exata como nos relatos antigos. Porém, enquanto esses relatos recorriam frequentemente ao miraculoso, é indispensável que a informação seja plausível”. Como trata-se de lenda tradicional do norte e nordeste do Brasil, o elo da identificação são a fauna e as personagens mostradas (pescadores, índios etc) que tornam o conto "compreensível de si e para si" (BENJAMIN, 1994, p. 203).

\section{EXPERIÊNCIA NORDESTINA NA NARRAÇÃO DE ZÉ ROTINHO}


As mentiras de seu Zé, na realidade, são conhecimentos correntes no interior do Brasil há séculos, principalmente com relação às onças e cobras. Como parte do maravilhoso, os contos visam o riso, o humor e o susto, utilizando-se da anatomia da fauna e da flora local como partida para tanto. Na boca de Zé Rotinho, pelos traços hiperbólicos, o maravilhoso se mostra. Sobre os pés das cobras, o contador ainda tem explicação melhor que a da sabedoria corrente:

Os pés da cobra são misteriosos, e se a gente botar, sexta-feira-da-Paixão, uma cobra morta, de papo pra cima, na areia quente, os pés aparecem, e são centenas. Pura abusão. As que sobem em pau são as que têm couro cheio de escamas. Ela arrepia as escamas e cada uma vai servindo de pé, agarrando-se na madeira (IBIAPINA, 1977, p. 109).

Sobre essas espécies e nomes de cobras, ele explica: "O interessante é a cobra-de-cipó. Voa dum pau pra outro. Certa ocasião, tive o cuidado de medir, porque foi mesmo um salto grande. Cinquenta e seis metros e meio" (IBIAPINA, 1977, p. 109). Ainda, para deixar as crianças assustadas, ele diz: "Eu ouvia dizer que cobra-preta mama em mulher, mas não acreditava. Vai que Guilhermina começou a se queixar que amanhecia o dia sem leite em seus depósitos” (IBIAPINA, 1977, p. 107).

O medo proporcionado pela inocência e o sentido de aconchego da comunidade foram registrados por Fontes Ibiapina, dizendo que as histórias que escrevia foram escutadas na infância, um apego não apenas deste escritor, mas de muitos nordestinos. Esse foi o relato de Luís da Câmara Cascudo que, além de explicar a importância da tradição para a cultura do lugar, deu seu próprio testemunho:

Os contos tinham divisões, espécies, gêneros, tipos, iam às adivinhações, aos trava-línguas, mnemônias, parlendas. Ia eu ouvindo e aprendendo. Não tinha conhecimento anterior para estabelecer confronto nem para subalternizar uma das atividades em serviço da outra. Era o primeiro leite alimentar da minha literatura. Cantei, dancei, vivi como outros meninos sertanejos do meu tempo e vizinhanças, sem saber da existência de outro canto, outra dança, outra vida (CASCUDO, 2012, p. 7).

Essa fala de Câmara Cascudo mostra a atribuição do autor, no que se refere à validade das histórias, à não existência de confronto entre saber científico tradicional e os saberes popularmente repassados. Ele delega a eficácia dos causos contados para as crianças ao desconhecimento de um mundo para além do universo infantil. Em especial, para as crianças do nordeste, que viviam longe da tecnologia, da eletricidade e das dinâmicas urbanas. Ainda pontuou o costume de contar e a atmosfera que o envolvia, 
comum ao nordeste brasileiro como um todo, algo que reforçava o pertencimento, o valor da palavra, o respeito ao mais velho, a perpetuação de histórias populares e a representação da inocência dos meninos e meninas da região.

E foi exatamente a infância o grande terreno do maravilhoso nordestino. No espaço imaginativo da infância e da juventude é que os contadores de histórias se debruçaram, porque a fronteira entre a representação e a realidade ainda aparece muito tênue nessa época, dando lugar às fantasias. Para a maioria, com a chegada da vida adulta, especialmente dos meninos moradores do interior do Nordeste, até à atualidade, precisam se deslocar aos centros urbanos do sudeste do Brasil e às capitais dos seus estados, pois é preciso conseguir profissionalização ou melhores condições de vida.

Essas crianças em Mentiras Grossas de Zé Rotinho são os ouvintes, que perguntam ou acompanham alguém que figura alguma narrativa. Seu Zé vai respondendo às perguntas com suas mentiras, tomadas pelos meninos como verdades, $\mathrm{o}$ que dá um tom engraçado à história. Em "Cobras, cobras e mais cobras” as crianças perguntam e o velho responde:

- E cobra-verde tem veneno?

- Tem não. E não podia ter. Verde é esperança, cor da mata e de legume na roça em ano de bom inverno. E pode olhar, que ela tem a ponta do rabo fino e a cabeça comprida. Dois sinais de cobra que não tem veneno. E é verde. Cor da esperança (IBIAPINA, 1977, p. 110).

O caráter alegórico que assume a mentira de seu Zé aponta para a alegria daqueles tempos que o autor descreve na saudade. $\mathrm{O}$ respeito à natureza e à fonte de subsistência do nordeste, que é a agricultura, se desvelam na fala do contador. Zé continua contando suas mentiras, criando o engraçado da história, usando-as, inclusive, quando não tem respostas a dar para as crianças que lhe perguntam:

\footnotetext{
- De onde vem o nome da cobra-de-veado?

- Porque ela berra como veado.

Um berro parecido com berro de cabrito. Aí o veado vem. Ela lança o pobre e mata de arrocho (IBIAPINA, 1977, p. 110).
}

Nessa conversa, seu Zé conhecia até o antídoto para não morrer por causa de uma picada de cobra venenosa, e ensinava às crianças: "É conhecido de todo mundo que o melhor remédio, que nunca falhou por uma vez, para ofendido de cobra é fel de paca" (IBIAPINA, 1977, p. 105). E acerca do veneno, para seu Zé os únicos animais que a cobra não ataca são o gato, pela velocidade, e o Gambá, porque "solta logo aquela 
mijada esguinchada e fedorenta que embriaga, e a desgraçada da cobra, de tão bêbada, fica sem a menor ação" (IBIAPINA, 1977, p. 111).

O deleite das crianças, assim, parece residir nessa diversidade e mutação de imagens, largamente evocadas pela voz do contador. A curiosidade e a imaginação trabalham à serviço do prazer de encontro com a arte literária, num processo que se torna uma espécie de sonho com vida à parte. Os medos e ilusões dessa fase da vida, em que a fronteira entre o devaneio e a certeza são fluidas, servem de alicerce, sobre o qual ergue-se o aspecto o lirismo do maravilho.

É por meio do devaneio, da brincadeira e do fantasioso que as crianças aprendem as lições da comunidade e para a idade adulta, o que dá autoridade às histórias contadas e onde mais se expressa o tom de "conselho" inerente a esse tipo de literatura, porque na narrativa "aconselhar é menos responder uma pergunta que fazer uma sugestão sobre a continuação de uma história que está sendo narrada" (BENJAMIM, 1994, p. 200). Foi esse o ponto que Walter Benjamin (1994) ocupou-se ao diferenciá-la do romance contemporâneo e da informação, sobretudo no caráter utilitário de narrativas como essa de Fontes Ibiapina, em que Zé Rotinho reside "seja num ensinamento moral, seja numa sugestão prática, seja num provérbio ou numa norma de vida” (BENJAMIN, 1994, p. 200).

\section{CONSIDERAÇÕES FINAIS}

À medida que seu Zé Rotinho vai contando as mentiras, ensina às crianças pequenos saberes, revelando, aqui pela ótica de Walter Benjamin (1994), as bases narrativas da sabedoria repassada pela literatura, que é a utilidade do conselho e da tradição na voz do contador; sem prejuízo do humor, contido no mirabolante do maravilhoso. De tal modo que Fontes Ibiapina insere-se na gama das narrativas a quem Benjamin tece o elogio de "verdadeiras", pois inúmeras vezes julgadas como arcaicas e pelo prisma do preconceito às pessoas mais velhas ou mais simples, para o estudioso, na verdade, concentram os vínculos que se desfazem desde o pós-guerras, no silêncio 
generalizado pela compartimentação da vida, com a rapidez informativa da contemporaneidade e o consequente isolamento humano.

Ainda, essas representações da infância na prosa de Ibiapina, denunciam a experiência do escritor, especialmente por registrar tradições passiveis de confronto com o registro dos historiadores. O que fica mais visível pela observação de sua biografia e nos detalhes que os textos revelam do histórico e do cotidiano do estado natal. Nascido na fazenda Lagoa Grande, em Picos, no interior do Piauí, Fontes Ibiapina foi alfabetizado no mesmo lugar. Ali viveu, ouvindo histórias, ajudando a família nos afazeres da agricultura, cuidando dos bichos e convivendo com o cotidiano dos vaqueiros da vizinhança. Ainda moço precisou abandonar o conforto juventude e seus brinquedos para estudar e trabalhar na cidade de Teresina. Muitas foram as dificuldades para manter-se na capital do estado e dedicar-se aos estudos.

Com ótimo desempenho, o menino sertanejo foi professor do Liceu Piauiense, entrou para a Faculdade de Direito e tornou-se juiz. Como fizeram outros escritores que precisavam sustentar-se e, ao mesmo tempo, produzir sua literatura, a escrita corria em paralelo ao trabalho, contando e escrevendo histórias para os filhos e amigos, como fizeram seus antepassados. Entretanto, esse ofício não foi para aquele contista apenas um passatempo. Pela análise de sua biblioteca, a quantidade de livros de estudo do Folclore e da literatura regional; as correspondências com intelectuais como Câmara Cascudo e o escritor Álvaro Ferreira; e suas agendas de trabalho, onde anotava as características dos réus e testemunhas pelo Piauí, demonstram o interesse desse escritor pelos tipos humanos de sua terra e pela cultura do nordeste. A dedicação foi reconhecida, pelo seu talento na representação do estado, o que the conferiu uma cadeira na Academia Piauiense de Letras.

A magistratura, no entanto, não o deixou quietar, porque circulava pelas cidades do estado do Piauí, demorando-se em cada região por pouco tempo. O desejo de retorno à terra e a ruptura com a vida de menino pelas cobranças da vida adulta aparecem marcantes nos seus textos, voltando-se ao vivido e ouvido naqueles tempos sempre que preciso. A saudade é uma marca forte na escrita de Fontes Ibiapina, inclusive, ladeando-o com demais escritores do Nordeste, cuja saudade de sua terra, por motivo do trabalho e na busca da sobrevivência, lhes foi companheira. A exemplo disso estão os 
poemas de Da Costa e Silva, nascido em Amarante, e os de Hindemburgo Dobal, de Campo Maior, considerados dois dos maiores poetas do Piauí.

A vida na fazenda, o cotidiano do sertão e as histórias ouvidas retornam pelos contos de Mentiras Grossas de Zé Rotinho, como numa tentativa de recuperar o elo de sua antiga morada e de preservá-la como uma memória comum à população de sua terra, algo que, entretanto, aparece para os tempos atuais como fonte relevante no estudo da cultura do interior da América Latina, pouco registrada por outros tipos de documentos históricos, salvo por obras como a de Ibiapina, Ariano Suassuna e outros literatos do nordeste do Brasil.

\section{REFERÊNCIAS BIBLIOGRÁFICAS}

BENJAMIN, Walter. Magia e técnica, arte e política. Tradução de Sérgio Paulo Rouanet. 7 ed. São Paulo: Brasiliense, 1994.

CANDIDO, Antonio. Iniciação à Literatura brasileira (resumo para principiantes). 3. ed. São Paulo: Humanitas, 1999.

CASCUDO, Luís da Câmara. Literatura oral no Brasil. São Paulo: Global editora, 2012.

CHIAMPI, Irlemar. O realismo maravilhoso: forma e ideologia no romance hispano-americano. São Paulo: Perspectiva, 2015.

DEMES, Josefina. Floriano: sua história, sua gente. Teresina: Halley, 2002.

IBIAPINA, João Nonon de Moura Fontes. Mentiras Grossas de Zé Rotinho: Contos populares do folclore no Piauí. Teresina: Caderno de Letras Meridiano, 1977.

RAMA, Angel. Um processo autonómico: de las literaturas nacionales a la literatura latino-americana. In.: Anais VII Congresso de La Associación Internacionale de Literature Comparate. Caracas: Universidade Central da Venezuela, 1979.

RIBEIRO, Verônica Maria Pereira; NUNES, Maria Cecília Silva de Almeida.

Manifestações Folclóricas. In.: SANTANA, Raimundo Nonato Monteiro de. Piauí: formação. Desenvolvimento. Perspectivas. Teresina: FUNDAP; Halley, 1995.

Recebido em: 18/08/2019

Aprovado em: 22/12/2019

Publicado em: 26/12/2019 